\title{
Wout Saelens
}

\section{Energie en materiële cultuur}

\section{Huishoudelijke verwarming en verlichting in de vroeg- moderne stad.}

Vroegmoderne energietransities (of het gebrek ervan) waren lang diepgeworteld in de huishoudelijke praktijken en gewoonten van stedelingen die het verbruik van energie voor verwarming en verlichting veronderstelden. Dit artikel probeert te illustreren hoe niet alleen veranderingen en continuiteiten in het aanbod van energie de huishoudelijke energieconsumptie hebben beïnvloed, maar ook hoe - omgekeerd - een veranderende materiële cultuur en consumptiepraktijk zelf energietransities hebben gemaakt. Daarin heeft de toenemende nadruk op comfort, gemak en huiselijkheid geleid tot een groeiende verspreiding van energie in huis.

Op 15 december 1777, kort na de dood van haar man Robert Jan Moerman - burggraaf en hoogbaljuw van het Land van Waas - kreeg Maria Theresia Robette twee bezoekers over de vloer in haar huis in de Bestorm Straete in Gent. ${ }^{1}$ Beide mannen - allebei kleerkopers - waren door de Gentse schepenen aangesteld als gezworen prijsijers en hadden de taak om alle 'meubelen ende catheijlen van huijsraede' te inventariseren en taxeren. Het opmaken van zo'n boedelinventaris was nodig om Maria als boedelhoudster bij te staan in de verdeling van de inboedel over haar vier minderjarige kinderen. De twee mannen lieten zich door Maria rondleiden en vatten de inventaris aan in de keuken. Daar moet meteen de haard zijn opgevallen, want de eerste opgetekende objecten waren onder meer 'vier roosters', 'drij kettingen', ' 3 staende ijserkens', een 'blaespijpe', '2 branders', een 'staende draeijende spit', een 'staenden hanghel', enzovoort. Verder hing in de haard nog een 'coeckpanne', een 'pod' en ander kookgerei, alsook een lade 
met 'solferstecken' - een soort vroege lucifers - waarmee het vuur werd aangestoken.

Wat verder in het huis kwamen de prijsijers in de 'eetplaetse' terecht, waar gasten gezellig konden aanschuiven aan één van de twee tafels en veertien stoelen die er werden geteld. De kamer was versierd met een kamerbehangsel en had maar liefst zestien schilderijen en enkele spiegels aan de muren hangen. Ook hier troffen de prijsijers een open haard aan, die duidelijk niet alleen een praktische maar ook decoratieve rol had. Boven de haard hingen namelijk twee 'printjens met vergulde lijsten' en waren de zijkanten voorzien van twee 'blaekerkens' voor extra licht. Ook in de volgende kamer - de 'groote salette' of de salon - was de schoorsteenmantel gedecoreerd met een porseleinen stel, een spiegel en twee wandluchters. Deze kamer moet er met haar kamerbehangsel en twee vergulde kroonluchters eveneens vrij imposant hebben uitgezien. Aan het diverse thee-, koffie- en chocoladeservies te zien, kon men er bovendien verschillende warme dranken consumeren een belangrijk achttiende-eeuws ritueel van huiselijke sociabiliteit. In deze publieke kamers speelde de haard een grote symbolische rol.

In een ander, veel minder frivool aangekleed kamertje, waar men van meubilair enkel een tafel en wat stoelen en banken terugvond, werd daarentegen verwarmd met een kachel. Ook de blikken lamp in de kamer was simpel en vooral kostenefficiënt - in tegenstelling tot de meer prestigieuze kandelaars die we vaak in de belangrijkere kamers van vroegmoderne huizen tegenkwamen. De twee kolenemmers in dat ene kamertje verraden trouwens dat hier met steenkool gestookt werd. Hoewel Maria en Robert via hun buitensteedse landerijen en bossen toegang hadden tot goedkoop brandhout - waarmee ze duidelijk wel de haard in de eetzaal deden branden - gaven ze in dit meer private kamertje de voorkeur aan steenkool, dat in laat-achttiende-eeuws Gent reeds de belangrijkste energiebron was geworden. Ook in het comptoir (of studeervertrek) van Robert en de slaapkamer van Maria stond een kachel.

Waar dergelijke (kolen)kachels een eeuw voordien in de meeste interieurs nog een onbekend zicht waren geweest, had ongeveer de helft van de Gentse huishoudens tegen het einde van de achttiende eeuw één of meerdere kachels geïnstalleerd. Ook Maria en Robert hadden blijkbaar het comfort en gemak van de kachel ingezien. Toch verloor de open haard daarmee niet meteen zijn functie. Integendeel, niet alleen waren haarden nog altijd de technologie bij uitstek waarmee gekookt werd, ook de symbolische waarde van de open haard had diepe historische wortels. Zeker in representatieve kamers bij rijke

\section{4}


families moest die als toonzetter voor de rest van het huiselijke decor nog vooral de eerbiedwaardigheid van het gezin etaleren. Warmte en licht waren dus heel bepalend voor de functies die een kamer kon vervullen.

De rondleiding in het Gentse stadspaleis van ruim dertig kamers van Maria en Robert gunt ons een blik op hoe (rijkere) huishoudens in de vroegmoderne tijd hun huis hebben verwarmd en verlicht. In dit artikel toon ik aan hoe historische energietransities in belangrijke mate geworteld waren in de sociale en culturele praktijken en gewoonten van het dagelijks leven. Dat doe ik aan de hand van de materiële cultuur van energie in verschillende steden en regio's in de vroegmoderne Nederlanden. ${ }^{2}$ Tot nu toe hebben historici de (vroeg)moderne energiegeschiedenis vooral geïnterpreteerd vanuit het perspectief van de veranderingen in het energieaanbod en de rol daarvan in industriële ontwikkelingen. ${ }^{3}$ Zo zouden nieuwe ontginningstechnieken, betere transportmiddelen en toenemende investeringen in kolenmijnen geleid hebben tot een groter en dus goedkoper aanbod van steenkool - zeker relatief aan het duurder wordende hout - wat op zijn beurt een positief effect zou hebben gehad op de industriële revoluties in Engeland en België bijvoorbeeld. ${ }^{4}$ Huishoudelijke energieconsumptie wordt daarentegen vaak aan de kant geschoven omwille van haar schijnbaar passieve karakter in de 'natuurlijke' verspreiding van steeds efficiëntere technologie. Uiteraard had de opkomst van nieuwe energiebronnen en energietechnologieën een groot effect op het particuliere verbruik. Maar achter de banaliteit van huishoudelijke verwarming en verlichting gingen ook heel wat consumptiestrategieën en -gedragingen schuil. De verspreiding van verwarmings- en verlichtingsobjecten in vroegmoderne huizen is daarom niet alleen te wijten aan de introductie van nieuwe kostenbesparende technieken, maar wijst ook op het toenemende belang van sociale en culturele categorieën zoals comfort, gemak en huiselijkheid.

De context: energieconsumptie in de vroegmoderne stad

Maria en Robert waren niet de enige in het achttiende-eeuws Gent die met steenkool stookten. In de loop van de achttiende eeuw schakelde Gent namelijk massaal over van brandhout naar steenkool als belangrijkste brandstof die vanuit de steenkoolbekkens aan de Samber en Maas over de Schelde werd ingevoerd. ${ }^{5}$ Daarmee was Gent één van de eerste steden in de Lage Landen - en op het Europese continent meer algemeen - die definitief 
op een fossiel energieregime overstapte. In andere steden in het graafschap Vlaanderen en het hertogdom Brabant bleef brandhout iets langer dominant en werd de energievoorziening hier en daar nog verder aangevuld met turf. ${ }^{6}$ In Antwerpen, waar sinds de zestiende eeuw de invoer van Hollandse turf een belangrijke aanvulling op de consumptie van brandhout was geweest, werd steenkool pas in de eerste helft van de negentiende eeuw echt belangrijk. ${ }^{7}$ Antwerpen was voor de import van steenkool vooral afhankelijk van de handel met Engeland, die in de achttiende eeuw sterk werd tegengewerkt door de protectionistische politiek van de overheid om vooral de productie rond Charleroi te stimuleren. ${ }^{8}$ In Brussel zorgde de nabijheid van het Zoniënwoud dan weer voor een vrijwel gegarandeerde toegang tot goedkoop brandhout. ${ }^{9}$ Waar stedelingen hun energievoorziening vooral op de markt moesten afstemmen, produceerden plattelandsbewoners hun brandhout doorgaans zelf door het aanplanten van houtkanten. ${ }^{10}$ De stijgende houtprijs door schaarste en bevolkingsgroei noopten echter steeds meer huishoudens in de Oostenrijkse Nederlanden - vooral in de steden - te zoeken naar alternatieve energiebronnen.

In de Noordelijke Nederlanden bleef tot ver in de negentiende eeuw turf de belangrijkste bron van warmte-energie. ${ }^{11}$ Deze 'semi-fossiele' brandstof was namelijk in grote hoeveelheden beschikbaar en de winning ervan werd dan ook gretig gecommercialiseerd sinds de late middeleeuwen. ${ }^{12}$ Steenkool werd in de Republiek sinds de veertiende eeuw wel ingevoerd, vanuit Engeland via Amsterdam en vanuit Luik via Dordrecht en Rotterdam, vooral voor specifieke industrieën zoals de brouwnijverheid. ${ }^{13}$ Maar de meeste, zowel industriële als particuliere, afnemers gaven consequent de voorkeur aan turf en werden daarin gesteund door de overheid, niet alleen omwille van de grote beschikbaarheid, maar ook omdat het properder was en aangenamer brandde dan steenkool. ${ }^{14}$ Wanneer de turfvoorraden stilaan uitgeput raakten, volgde een transitie naar steenkool in Nederland pas aan het begin van de twintigste eeuw. ${ }^{15}$

Recent onderzoek heeft aangetoond dat gemakkelijk driekwart van alle geconsumeerde energie in verschillende steden van vroegmodern Europa voor huishoudelijke activiteiten werd aangewend. Zo wees ecologisch historicus William M. Cavert erop dat steenkool reeds twee eeuwen voor de introductie van de stoommachine van James Watt al volop werd geconsumeerd door de vele huishoudens in het zeventiende- en achttiende-eeuws Londen. ${ }^{16}$ Ook in een stad als Gent leverden rond 1850, toen de industrialisering volop aan de gang was, de zowel gemechaniseerde als traditionele industrieën een aandeel 
van slechts ca. 25 procent in de totale stedelijke energieconsumptie. ${ }^{17}$ Ook voor Nederland heeft het onderzoek van M.A.W. Gerding aangetoond dat de stijging van de turfproductie in de noordelijke provincies van het land in de negentiende eeuw vooral werd aangedreven door een toenemende vraag naar energie vanuit de huishoudeconomie. Niet alleen het groeiende b e volking sa a n a l maar ook de groeiende energiebehoefte per hoofd deed de vraag naar energie namelijk stijgen. ${ }^{18}$ Het mag dus duidelijk zijn dat de huishoudelijke vraag alleen al vanuit een louter kwantitatief oogpunt heel belangrijk was voor energietransities (of het gebrek ervan) in het

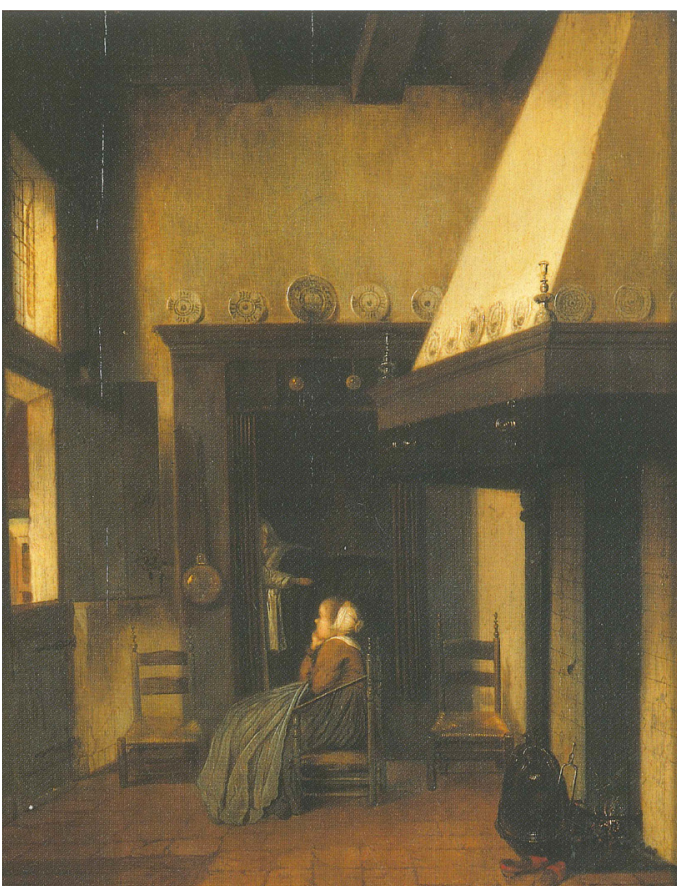

Afbeelding 1. Jacob Vrel, Meisje bij ziekbed, 1650-1660. Versierd met aardenwerken schotels en twee kandelaren valt de ouderwetse hangende rookkap van de schouw in dit zeventiende-eeuwse Hollandse interieur meteen op. Aan de schouwbalk zijn twee komforen aan ringen bevestigd - dicht bij het haardvuur zodat de hete kolen er direct konden worden ingegooid. Naast het haardgerief staat ook een vuurstolp waarmee 's nachts het vuur werd afgedekt om brand te voorkomen. Bij het hoofdeinde van de bedstede hangt verder ook een beddenpan. Afbeelding: Antwerpen, verleden.

\section{Van haard naar kachel?}

Dat huishoudelijke verwarming nauw samenhing met de bredere tendenzen in de energiegeschiedenis, blijkt ook uit boedelonderzoek. In de loop van de achttiende eeuw zien we in Gentse boedels de aanwezigheid van steenkool stijgen van 33 procent in 1680 naar 88 procent in 1830, terwijl de verspreiding van brandhout in die jaren zakte van 88 procent naar 47 


\section{Saelens}

procent. ${ }^{19}$ In een stad als Leiden daarentegen wijzen zo'n 90 procent van een reeks boedelinventarissen uit de jaren 1680, 1730, 1780 en 1830 op de aanwezigheid van turf als voornaamste brandstof. Brandhout was in 1680 nog in ongeveer 30 procent van de boedels aanwezig, maar zakte tegen het einde van de achttiende eeuw weg tot slechts 23 procent. ${ }^{20}$ Op het platteland was brandhout de meest verspreide brandstof. ${ }^{21}$ Het lijkt erop dat steenkool en turf in respectievelijk de Zuidelijke en Noordelijke Nederlanden vooral stedelijke brandstoffen waren, waar deze energiebronnen doorgaans volledig gecommercialiseerd waren.

De overgang naar steenkool had duidelijk een effect op de popularisering van de kachel. In Gent steeg de aanwezigheid van kachels van 10 procent in 1730 over 55 procent in 1780 tot 91 procent in 1830 . Gent speelde hier als vroege steenkoolstad een voortrekkersrol in, want in de meeste andere steden (en dorpen) bleef de definitieve doorbraak van de kachel uit tot na de industriële revolutie. In Leiden bijvoorbeeld, een stad met een heel soortgelijk sociaal-economisch profiel als dat van Gent, kende de kachel in de achttiende eeuw een vrij constante verspreiding van hoogstens 15 procent. ${ }^{22}$ Zoals gezegd, was turf hier de brandstof bij uitstek en die brandde perfect in een open haard, in tegenstelling tot steenkool die bij verbranding veel giftige rook afgaf. Naast een betere verwarming zorgde de kachel dus ook voor een betere afvoer van die rook naar buiten toe. Pas aan het begin van de negentiende eeuw nam de populariteit van de kachel in het algemeen toe, toen in ongeveer 34 procent van de Leidse huishoudens een kachel opdook. De verandering van haardvuur naar kachel is ook een verandering die historicus Anton Schuurman reeds opmerkte in de materiële cultuur van de 'typisch Nederlandse' huiselijkheid die in de

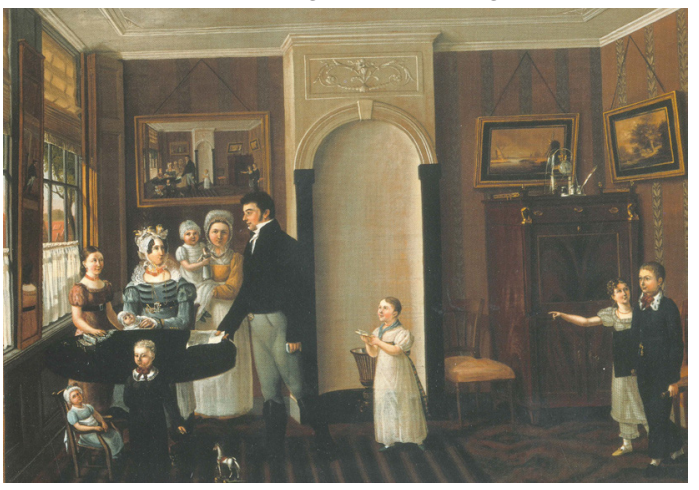

Afbeelding 2. Casparus Johannes Morel, De familie Horstman, 1823. Aan het begin van de negentiende eeuw wint de kachel aan populariteit. Een theestoof neemt in de nis de plaats van een kolomkachel in, wat suggereert dat dit portret in de zomer is negentiende eeuw als de 'age of domesticity' hoogtij vierde. ${ }^{23}$ tgelegd. Kennelijk werden kachels tijdens de warmere periodes van het jaar liever opgeborgen. Misschien omdat zulke grote ijzeren dingen niet altijd even elegant in het interieur opgingen. Afbeelding: Amsterdam, Historisch Museum. 
Maar de opkomst van de kachel stond niet meteen garant voor een snelle neergang van de open haard, zoals ik in de inleiding reeds aangaf. Haardgerei vinden we tot ver in de negentiende eeuw in zowat alle huishoudens van de Lage Landen terug. Zo was het gemiddelde vroegmoderne huis voorzien van twee haarden, die in de loop van de achttiende en negentiende eeuw eventueel nog werden aangevuld door één of twee kachels. Ook de grote verspreiding van schoorsteenkleedjes, porselein op de schouw en schoorsteenspiegels wijst op het blijvende belang van de haard in het achttiende-eeuwse interieur. In zijn boek Jongmans Onderwyser uit 1759 beschrijft Johann Herman Knoop hoe de schouw inderdaad het focuspunt van decoratie was: 'De Camyns behoren tot naar boven met Lyst- en Snywerk fraai opgemaakt en met Spiegels of Schilderyen verciert, als mede zodanig geschikt te worden (te weten in fraaje Pronk- en andere Kamers) dat men 'er Pastelein en andere Rariteiten op plaatzen kan. ${ }^{.24}$

Los van haar centrale rol in de decoratieve inrichting van het huis, werd de haard ook comfortabeler. Dankzij de introductie van schouw en schoorsteen was het haardvuur sedert de late middeleeuwen al naar de zijwand van de kamer verschoven, waardoor meerdere kamers tegelijk verwarmd konden worden. ${ }^{25}$ De verdere ontwikkeling van de imposante open haarden met hangende rookkap in de loop van de vroegmoderne tijd tot compactere en lagere schouwen - hoewel vooral geïnspireerd op Franse modellen soms ook wel 'Engelse schouwen' genoemd - die ook aan de zijkant met wanden waren uitgerust, doet inderdaad vermoeden dat ook de haard steeds aangenamer en voordeliger gestookt moest kunnen worden. ${ }^{26}$

Lang bestonden haard en kachel dus naast elkaar. De symbiose tussen beide verwarmingselementen wordt mooi geïllustreerd wanneer we in contemporaine boedelinventarissen 'ijzeren haarden' of 'ijzeren schoorstenen' zien opduiken. Zo vinden we in een inventaris van Jan Tak, een Leidse dokter die op 14 mei 1780 was overleden, een 'ijser haartje' voorzien van twee 'vergulde branches' in het 'groot salet' van zijn sterfhuis in de Breestraat. Ook in de kamer ernaast, het 'kleijne salet', stond een 'ijser haartje met kopere pooten en dito rant' te pronken naast enkele geschilderde mahoniehouten buffettafels met twee prestigieuze fauteuils en vier stoelen afgewerkt met geel trijp. ${ }^{27}$ De ijzeren haard was een type kachel die ontworpen was als een haard en combineerde als het ware het beste van twee werelden: het comfort van de kachel en het elegante karakter van de haard. Vooral in de eerste helft van de negentiende eeuw zou de ijzeren haard heel populair worden. 
Mobiel comfort: komforen, beddenpannen en voetstoven

Naast de haard en kachel die gebruikt werden om hele vertrekken te verwarmen, waren er nog een aantal kleinere warmteartikelen die we in achttiende-eeuwse huizen terugvonden. De sterke stijging van komforen in de achttiende eeuw duidt op het toenemende belang van kleine en mobiele energiehouders. Gevuld met gloeiende kolen (zowel houts-, steen- als turfkolen) werden komforen gebruikt voor verwarming en als kooktoestel. Kookkomforen waren doorgaans gemaakt van ijzer en kunnen beschouwd worden als

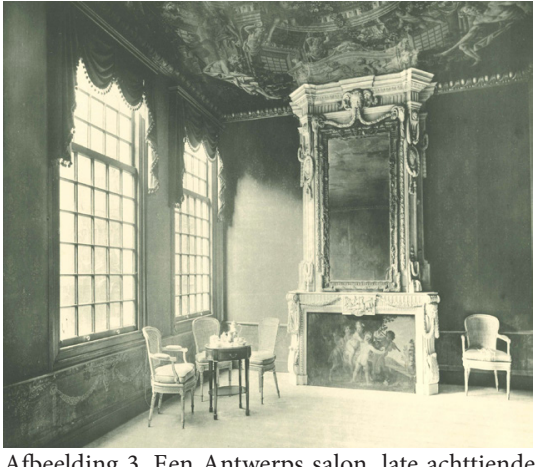

Afbeelding 3. Een Antwerps salon, late achttiende eeuw. De spaarzame meubilering in deze salon mocht bij het ontvangen van gasten vooral de aandacht niet afleiden van de imposante haard. De spiegel versterkte het licht en verving meer en meer de rol van schilderijen als voornaamste decoratie aan de schouw. Wanneer ze in de zomer niet gebruikt werd, kon de haard wel nog met een schilderij afgedekt worden. Afbeelding: K. Sluyterman, Oude binnenhuizen in België (Antwerpen: Boekhandel Forst, 1913), 14.

een vroege vorm van het moderne fornuis. ${ }^{28}$ Waarschijnlijk is het toenemende gebruik van kookkomforen gelinkt aan de geleidelijke overgang in de kookcultuur van het stoven en koken naar het bakken en braden van voedsel. Komforen vereisten immers het gebruik van potten en pannen met platte bodem, in tegenstelling tot de typische kookketels die aan een haardhaal werden gehangen of op een treeft geplaatst. De meer luxueuze types komforen, gemaakt van koper, zilver of tin, werden gebruikt om borden na het serveren warm te houden op tafel. ${ }^{29}$ In de loop van de vroegmoderne tijd groeide de keuken meer en meer uit tot een gespecialiseerde ruimte waarin enkel nog gekookt en niet langer gegeten werd. ${ }^{30}$ Ook het nuttigen van warme dranken zoals koffie en thee als nieuwe consumptiegewoonte had een effect op de groeiende nood aan mobiele energiedragers. In een boedelinventaris uit 1779 van de Leidse textielondernemer Pieter de Wilde vonden we in de keuken naast de eetzaal behalve enkele tafelkomforen bijvoorbeeld ook verschillende thee- en koffiekomforen die gebruikt konden worden om verse koffie of thee warm te serveren op de buffetkast in de kamer ernaast. ${ }^{31}$ Ook het 'tabaksconfoortje' dat in de tinnenkast was opgeborgen, kon bij dergelijke fraaie gelegenheden aangewend worden om de pijp te roken, een symbool van (vooral mannelijke) respectabiliteit. ${ }^{32}$ 
Ook aan de voeten had men het graag comfortabel warm. Tapijten, vloerkleden en karpetten hadden uiteraard een decoratieve functie maar bedekten in toenemende mate ook koude vloeren. Voetstoven kenden een groeiende verspreiding in de loop van de achttiende eeuw. Dit waren meestal houten kastjes waarin een test met vuur geplaatst werd. Hi erboven konden vervolgens de voeten warm gehouden

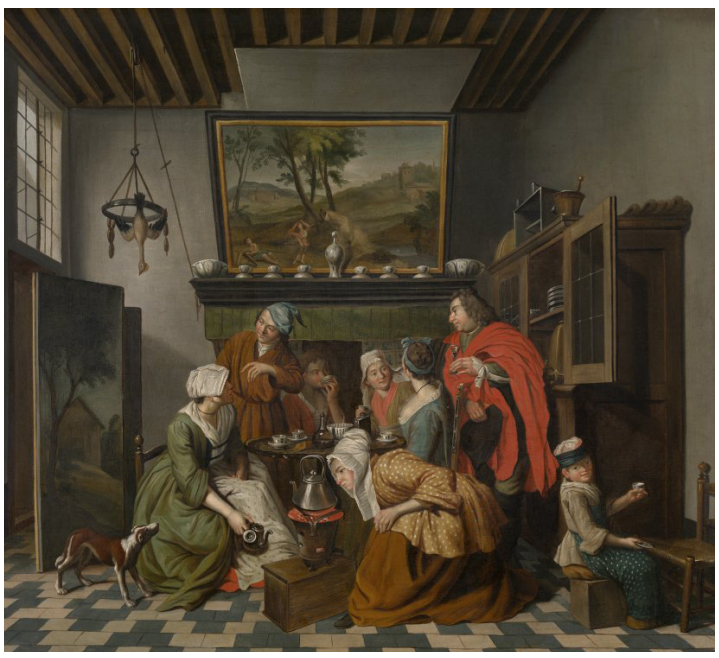

Afbeelding 4. Jan Jozef II Horemans, Het thee-uurtje, achttiende eeuw. Een gezin geniet samen met gasten van het thee-uurtje, een typisch huiselijk tafereel in de achttiende eeuw. De huisvrouw houdt in de voorgrond de verse theeketel warm met een dito komfoor. Afbeelding: Antwerpen, Koninklijk Museum voor Schone Kunsten.

worden. ${ }^{33}$ Stoven waren soms ook uit tin, blik, koper of zilver vervaardigd en hadden in die gevallen waarschijnlijk een soortgelijke functie als komforen. Beddenpannen of -stoven werden tot slot, net als komforen, gevuld met hete kolen en dienden om het bed te verwarmen tijdens koude nachten. ${ }^{34}$ In de achttiende eeuw lijkt het gebruik van zulke mobiele warmtehouders als komforen, beddenpannen en voetstoven erg groot te zijn geweest, wat verder bijdroeg aan de verspreiding van warmte in huis. ${ }^{35}$

\section{Meer licht in huis}

Uiteraard had de overgang naar fossiele brandstoffen in de eerste plaats een effect op hoe huishoudens verwarmden en kookten. Maar het verwarmen van het huis kon niet los gezien worden van het verlichten van het huis. Verschillende historici hebben de rol van licht in het vroegmoderne burgerinterieur reeds benadrukt. Zo pikte John E. Crowley verlichting uit als één van de meest fundamentele aspecten van de 'ontdekking van comfort' in vroegmodern Engeland. ${ }^{36}$ De haard voorzag uiteraard al in de behoefte aan licht. En misschien deed de geleidelijke overgang van 


\section{Saelens}

haardvuur naar kachel de nood aan verlichtingsobjecten in het huis toenemen. Tot het einde van de negentiende eeuw waren de meeste kachels inderdaad niet uitgerust met vensterglas. ${ }^{37}$ Reeds in de zeventiende eeuw beschikten de meeste huishoudens over artificiële verlichting. Vooral het aantal verlichtingsartikelen per huishouden steeg sterk naar het einde van de vroegmoderne tijd toe. In Gent bezat een gemiddeld huishouden voor 1700 ongeveer zes objecten die gerelateerd waren aan het verlichten van het huis. Rond 1800 was dit aantal al meer dan verdubbeld. In Leiden hadden huishoudens gemiddeld meer verlichtingsartikelen: een negental op het einde van de zeventiende eeuw, wat ook weer verdubbelde tegen het einde van de achttiende eeuw. ${ }^{38}$

Vooral de kandelaar was verantwoordelijk voor de vroegmoderne verlichting. Gedurende de zeventiende en achttiende eeuw bleef dit de belangrijkste bron van licht. De lantaarn, nog zo'n eeuwenoud verlichtingsinstrument, kende een kleinere verspreiding en werd vooral gebruikt in grotere ruimtes of in open ruimtes zoals de (binnen)plaats. Een belangrijkere evolutie was de snelle opkomst van nieuwere, simpelere verlichtingsartikelen. Olielampen en blakers waren minder prestigieus maar gebruiksvriendelijker dan kandelaars. ${ }^{39}$ Ze konden gemakkelijk door het huis heen verplaatst worden, al naargelang waar licht nodig was - bijvoorbeeld in het comptoir bij het schrijven van een brief, in de slaapkamer bij het slapengaan, of in een achterkamertje waar men las of een gezelschapsspel speelde. De meest opzichtige types van verlichting zoals kroonluchters kwamen minder voor en waren gereserveerd voor aristocratische en bourgeois-huishoudens.

Kaarsen waren in vergelijking met lampenolie duurder maar gaven wel een helderder licht af. Kandelaars verloren dan ook hun waarde niet meteen, zeker bij aangelegenheden waar meer aangenaam en overvloedig licht de voorkeur genoot. Zo zorgde een kaarspannetje in de bescheiden Gentse woning van Marie Joanne Caesteker, de op 12 maart 1780 overleden vrouw van schoenmaker Judocus Beijs, naast het haardvuur in de keuken voor wat extra licht bij het koken, het strijken, het doen van de was en enkele andere banale huishoudelijke activiteiten die hier lijken te hebben plaatsgevonden. In de 'benede camer', waar een tiental 'talliooren', twee 'peperdoosen', 'serveeten', enkele 'tassen en schaelen', twee 'caffe cannen' en ander tafelgerei suggereren dat hier vooral gegeten en gedronken werd, waren twee tinnen en één zilveren kandelaar verantwoordelijk voor het licht in de kamer. Ook de spiegel aan de muur had hierin een ondersteunende functie. Met de zilveren snuiter 
kon men eventueel de pit van de kaarsen afknippen om het walmen van de brandende kaars te voorkomen. ${ }^{40}$

Naast het artificiële licht van kandelaars en lampen drong ook natuurlijk licht steeds dieper door in de vroegmoderne woonkamer. We weten vanuit de architectuurgeschiedenis dat gevels meer en meer van vensters waren voorzien. Bakstenen gevelconstructies lieten ook steeds grotere vensteropeningen toe, waardoor vooral de voorste kamers aan de straatzijde konden genieten van een grotere lichtinval. ${ }^{41}$ Via boedelinventarissen kunnen we minder direct het aantal vensters van een huis afleiden, maar ook daar vinden we bijvoorbeeld steeds meer glasgordijnen terug.

\section{Slotbeschouwing}

De diversificatie in de materiële cultuur van verwarming en verlichting maakte de functie van energie in het vroegmoderne huis meer inzetbaar in verschillende huiselijke contexten. Licht en warmte werden in toenemende mate 'gemakkelijker', 'comfortabeler' en 'huiselijker'. De kachel zorgde voor een betere verspreiding van warmte. Zeker wanneer verwarmd werd met steenkool was de kachel de beste oplossing, niet alleen omdat steenkool een hogere energie-intensiteit leverde maar ook omdat de rook van brandende steenkool er beter werd in opgevangen. Energietransities bepaalden dus in belangrijke mate hoe in huis gestookt werd. Maar huishoudens eigenden ook zelf in grote mate veranderingen (of continuïteiten) in de economie van energie toe door nieuwe energietechnologieën in te passen in hun eigen wooncultuur. Het blijvende belang van de haardstede, waarin men het vuur tenminste nog zag en hoorde knetteren, als de meest opzichtige plaats van het huis toont aan dat energietransities in het verleden niet zomaar een verhaal waren van nieuwe, efficiëntere technieken die geleidelijk aan hun ingang vonden in het huishouden. De toenemende verspreiding van verschillende verwarmings- en verlichtingsobjecten was dan ook gelinkt aan verschillende andere belangrijke processen in het vroegmoderne huis en zijn materiële cultuur. We vermeldden reeds de warme-drankencultuur en andere vormen van huiselijke sociabiliteit die een goed verlichte en verwarmde kamer vereisten. Maar ook het groeiende aantal kleinere kamers bijvoorbeeld was wellicht een proces dat het gebruik van energie in huis moest maximaliseren. Wooncomfort, huiselijkheid en decoratieve inrichting waren categorieën waarvoor vooral de stedelijke middengroepen steeds gevoeliger werden. 


\section{Saelens}

Het typische burgerinterieur van de zeventiende- en achttiende-eeuwse Nederlanden voorzag inderdaad meer en meer in een warme huiselijke sfeer.

\section{Noten}

1. Wat volgt, is gebaseerd op Stadsarchief Gent (hierna: SAG), reeks 332, Minuten van staten van goederen, nummer $771 / 7$.

2. Ik focus vooral op Gent (graafschap Vlaanderen) en Leiden (graafschap Holland) als de twee casussteden die ik onderzoek in mijn doctoraat.

3. Zie vooral: E.A. Wrigley, The Path to Sustained Growth: England's Transition from an Organic Economy to an Industrial Revolution (Cambridge: Cambridge University Press, 2016); Robert C. Allen, The British Industrial Revolution in Global Perspective (Cambridge: Cambridge University Press, 2009).

4. Zie onder meer: John Nef, The Rise of the British Coal Industry (Londen: Routledge, 1932); Michael W. Flinn, The History of the British Coal Industry (Oxford: Clarendon Press, 1984-1993); Ben Gales, Delven en slepen. Steenkoolmijnbouw in Limburg: techniek, winning en markt gedurende de achttiende en negentiende eeuw (Hilversum: Verloren, 2004); Hervé Hasquin, Une mutation. Le pays de Charleroi aux 17e et 18e siècles: aux origines de la révolution industrielle en Belgique (Brussel: Institut de sociologie, 1971).

5. Wouter Ryckbosch en Wout Saelens, "Towards an energy revolution in Flanders and Holland? Energy consumption and the industrial revolution in Ghent and Leiden (c. 1650-1850)" (ter perse).

6. Christian Vandenbroeke, "De problematiek van de energievoorziening in de zuidelijke Nederlanden en inzonderheid in Vlaanderen (15de-19de eeuw)", Belgisch Tijdschrift voor Filologie en Geschiedenis 73, nr. 4 (1995): 967-981.

7. Thomas Braspenning, Een warm nest? De brandstofvoorziening van het achttiendeeeuwse Antwerpen (onuitgegeven masterthesis, Universiteit Antwerpen, 2016), 11-13.

8. Hervé Hasquin, "Nijverheid in de Zuidelijke Nederlanden, 1650-1795", in Algemene Geschiedenis der Nederlanden, ed. Dirk Peter Blok et al. (Haarlem: Fibula-Van Dishoeck, 1979), deel 8, 136-138.

9. Hilde Verboven, Het bos doorheen de bomen. Bijdrage tot de institutionele, ecologische en financieel-economische geschiedenis van het Zoniënwoud in de 18de eeuw (onuitgegeven licentiaatsverhandeling, Katholieke Universiteit Leuven, 1988) 64-72.

10. Sander Berghmans en Lies Vervaet, "Hout als energiebron in vroegmodern Vlaanderen", in Wereldgeschiedenis van Vlaanderen, ed. Marnix Beyen et al. (Antwerpen: Polis, 2018), 251-257.

11. J.W. De Zeeuw, "Peat and the Dutch Golden Age: the historical meaning of energyattainability", AAG Bijdragen 21 (1978): 3-32; R.W. Unger, "Energy sources for the Dutch Golden Age: peat, wind, and coal", in Research in Economic History: An Annual

\section{4}


Compilation of Research, ed. P.J. Uselding (Greenwich: Jai Press Inc., 1984), deel 9, 221-253; Jan Luiten van Zanden, "Werd de Gouden Eeuw uit turf geboren? Over het energieverbruik in de Republiek in de zeventiende en achttiende eeuw", Tijdschrift voor Geschiedenis 11 (1997): 484-499.

12. Petra van Dam, "Het onderaardse bos. Chronologische afbakeningen in de ecologische geschiedenis", Tijdschrift voor Sociale Geschiedenis 28 (2002): 192-195; Charles Cornelisse, Energiemarkten en energiehandel in Holland in de late middeleeuwen (Hilversum: Verloren, 2008).

13. Zeger Willem Sneller, Geschiedenis van den steenkoolhandel van Rotterdam (Groningen: Wolters, 1946), 80-98.

14. P. Van Schaik, "De economische betekenis van de turfwinning in Nederland (II)", Economisch- en sociaal-historisch Jaarboek 33 (1971): 201-220.

15. Ben Gales et al. "North versus South: energy transition and energy intensity in Europe over 200 years", European Review of Economic History 11 (2007): 224.

16. William M. Cavert, "Industrial coal consumption in early modern London", Urban History 44, nr. 3 (2017): 424-443.

17. Databank industriële energieconsumptie Gent - Wout Saelens, doctoraatsproject "Domestic energy consumption before and during the early industrial revolution: Belgium and the Netherlands compared (1600-1850)", Universiteit Antwerpen en Vrije Universiteit Brussel.

18. M.A.W. Gerding, Vier eeuwen turfwinning: de verveningen in Groningen, Friesland, Drenthe en Overijssel tussen 1550 en 1950 ('t Goy-Houten: HES, 1995), 326-331.

19. Databank boedelinventarissen Gent - Wout Saelens, doctoraatsproject "Domestic energy consumption before and during the early industrial revolution: Belgium and the Netherlands compared (1600-1850)", Universiteit Antwerpen en Vrije Universiteit Brussel.

20. Databank boedelinventarissen Leiden - Wout Saelens, doctoraatsproject "Domestic energy consumption before and during the early industrial revolution: Belgium and the Netherlands compared (1600-1850)", Universiteit Antwerpen en Vrije Universiteit Brussel.

21. Johan A. Kamermans, Materiële cultuur in de Krimpenerwaard in de zeventiende en achttiende eeuw: ontwikkeling en diversiteit (Hilversum: Verloren, 1999), 89; Carl Schelstraete, Hilde Kintaert en Dorine De Ruyck, Het einde van de onveranderlijkheid: arbeid, bezit en woonomstandigheden in het Land van Nevele tijdens de 17e en de 18e eeuw (Nevele: Heemkundige Kring van het Land van Nevele, 1986), 186.

22. Databanken boedelinventarissen Gent en Leiden - Wout Saelens.

23. Anton J. Schuurman, "Is huiselijkheid typisch Nederlands? Over huiselijkheid en modernisering", Bijdragen en Mededelingen betreffende de Geschiedenis der Nederlanden 107, nr. 4 (1992): 745-759.

24. Johann Herman Knoop, Jongmans onderwyser (Amsterdam, 1769), deel 2, 487.

25. John E. Crowley, The Invention of Comfort: Sensibilities and Design in Early Modern Britain and Early America (Baltimore: John Hopkins University Press, 2001), 22.

26. Jet Pijzel-Dommisse, "1700-1750", in Het Nederlandse interieur in beeld, 1600-1900, ed. Willemijn C. Fock (Zwolle: Waanders, 2001), 193-194. 


\section{Saelens}

27. Gemeentearchief Leiden (hierna: GAL), Oud Notarieel Archief (hierna: ONA), CLXXXIII - Archief van notaris Passchier Soetbrood, 1757-1803, nummer 2373.

28. Jozef Weyns, Volkshuisraad in Vlaanderen: naam, vorm, geschiedenis, gebruik en volkskundig belang der huiselijke voorwerpen in het Vlaamse land van de middeleeuwen tot de Eerste Wereldoorlog (Beerzel: Ter Speelbergen, 1974), 59-62.

29. Ibidem, 62-63.

30. Inneke Baatsen, Bruno Blondé en Julie De Groot, “The kitchen between representation and everyday experience. The case of sixteenth-century Antwerp", in Trading Values in Early Modern Antwerp, ed. Christine Göttler, Bart Ramakers en Joanna Woodall (Leiden: Brill, 2014), 162-185; Merwin Corbeau, "Pronken en koken. Beeld en realiteit van keukens in het vroegmoderne Hollandse binnenhuis", in Mensen en dingen. Betekenissen van materiële cultuur, ed. Gerard Rooijakkers (Amsterdam: P.J. Meertens-Instituut, 1993), 354-379.

31. GAL, ONA, CLXXXIX - Archief van notaris Albertus Kleynenbergh Jansz., 17681811 , nummer 2548.

32. Woodruff D. Smith, Consumption and the Making of Respectability, 1600-1800 (New York: Routledge, 2002), 161-169.

33. Weyns, Volkshuisraad, 66-67.

34. Ibidem, 69-71.

35. Kamermans, Materiële cultuur, 87-88, Anton J. Schuurman, Materiële cultuur en levensstijl: een onderzoek naar de taal der dingen op het Nederlandse platteland in de 19de eeuw: de Zaanstreek, Oost-Groningen, Oost-Brabant (Utrecht: HES, 1989), 73; Thera Wijsenbeek-Olthuis, Achter de gevels van Delft: bezit en bestaan van rijk en arm in een periode van achteruitgang (1700-1800) (Hilversum: Verloren, 1987), 355.

36. Crowley, The Invention of Comfort.

37. Priscilla J. Brewer, "We have got a very good cooking stove': advertising, design, and consumer response to the cookstove, 1815-1880", Winterthur Portfolio 25, nr.1 (1990): 35-54.

38. Databanken boedelinventarissen Gent en Leiden - Wout Saelens.

39. Weyns, Volkshuisraad, 719-740.

40. SAG, reeks 332, nummer 771/20.

41. Inneke Baatsen et al., "Thuis in de stad: dynamieken van de materiële cultuur", in Gouden Eeuwen: stad en samenleving in de Lage Landen, 1100-1600, ed. Anne-Laure Van Bruaene, Bruno Blondé en Marc Boone (Gent: Academia Press, 2016), 257-258. 